\title{
Two new species of Henneguya Thélohan, 1892 (Myxozoa, Myxobolidae), parasitic on the gills of Hoplosternum littorale (Callichthyidae) and Cyphocharax gilbert (Curimatidae) from the Guandu River, State of Rio de Janeiro, Brazil
}

\author{
VANESSA D. ABDALLAH*, RODNEY K. DE AZEVEDO*, JOSÉ LUIS LUQUE** \\ e TERESA C. B. DO BOMFIM**
}

\begin{abstract}
Two new species of Henneguya (Myxozoa) were described from specimens collected on the gills of Hoplosternum littorale (Hancock, 1828) (Callichthyidae) and Cyphocharax gilbert (Quoy and Gaimard, 1824) (Curimatidae), from Guandu River, State of Rio de Janeiro, Brazil. The species described were compared with the related species of the genus. The new species of Henneguya parasitic on $\boldsymbol{H}$. littorale has cysts with synchronous development, the spore body was 14.6 (11.4-16.7) $\mu m$ long by 6.5 (4.9-7.9) $\mu \mathrm{m}$ wide. The total length of the spore was 33.6 (27.3-38.1) $\mu \mathrm{m}$ and each valve had a caudal process measuring 19.0 (15.6-22.5) $\mu \mathrm{m}$. The larger polar capsule was 4.4 (3.35.6) $\mu \mathrm{m}$ long by 2.0 (1.6-2.3) $\mu \mathrm{m}$ wide, the smaller polar capsule was 4.1 (3.3-5.3) $\mu \mathrm{m}$ long by 2.2 (1.5-2.8) $\mu \mathrm{m}$ wide. Each polar filament with 3-6 coils. The new species of Henneguya parasitic on C. gilbert has cysts with synchronous development, the spore body was 11.3 (7.7-13.4) $\mu \mathrm{m}$ long by 4.4 (2.9-6.3) $\mu \mathrm{m}$ wide. The total length of the spore was 35.1 (29.6-44.4) $\mu \mathrm{m}$ and each valve had a caudal process measuring 23.7 (20.8-31.5) $\mu \mathrm{m}$. The larger polar capsule was 5.2 (4.2-6.3) $\mu \mathrm{m}$ by 1.9 (1.5-2.3) $\mu \mathrm{m}$ wide, the smaller polar capsule was 4.5 (3.4-5.2) $\mu \mathrm{m}$ long by 1.7 (1.3-2.2) $\mu \mathrm{m}$ wide. Each polar filament with 7-9 coils. The characteristics of these species were compared with all the species described so far.
\end{abstract}

Key words: Henneguya guanduensis n. sp., Henneguya cyphocharax n. sp., Guandu River, Myxozoa, Brazil.

\section{INTRODUCTION}

Currently, Myxozoa contain 52 genus $^{1}$, many of them are parasites of fish. Henneguya, is the second largest within Myxozoa and it contains about 150 described species ${ }^{2}$. Eiras $(2002)^{2}$ listed 146 species in Henneguya. Since then, more nine species were described parasitic Brazilian

* Curso de Pós-Graduação em Ciências Veterinárias, Universidade Federal Rural do Rio de Janeiro, Seropédica, Brasil.

** Departamento de Parasitologia Animal, Universidade Federal Rural do Rio de Janeiro, Caixa Postal: 74.508, Seropédica, Brasil, CEP: 23890-971. 
freshwater fishes ${ }^{3-11}$. In total, there are currently 29 species described for Brazilian fishes ${ }^{12-17}$. This number is surprisingly low when compared with the high number of fish species in Brazilian rivers ${ }^{6}$. The importance of these species as pathogens of freshwater fish has been described by several authors ${ }^{18}$. In 1997 , occur the report of spores of Henneguya salminicola in human stool specimens, but no exist evidence that these parasites are capable of causing disease in humans ${ }^{19}$.

None species of Henneguya was recorded from Guandu River, which is the most important source of water supply of the city of Rio de Janeiro and characterized as the fluvial system with the highest fish biodiversity in the Basin Hydrographic of the Bay of Sepetiba ${ }^{20}$.

During a parasitological survey of fishes of Guandu River, were collected numerous cysts of Myxozoan on the gills of Hoplosternum littorale and Cyphocharax gilbert. In the present paper, two new species of Henneguya are described and illustrated.

\section{MATERIAL AND METHODS}

Between May 2004 to February 2005, were collected 100 specimens of $H$. littorale and 60 specimens of $C$. gilbert from the River Guandu (22 $\left.48^{\prime} 32^{\prime \prime} \mathrm{S}, 43^{\circ} 37^{\prime} 35^{\prime \prime} \mathrm{W}\right)$, State of Rio de Janeiro, Brazil. Once obtained, the fish were conditioned in boxes containing ice, to assure adequate conditions for the collection of the parasites and transport to laboratory. The fish were thoroughly dissected under a compound microscope and all the organs were inspected for the presence of parasites.

Thirty free spores from freshly prepared material obtained from different fish specimens were measured using a micrometer (Wild-PZO) $15 X$, coupled to a microscopy Leitz Wetzalar Dialux 20 EB under 10X for the measurement of the cysts and it aims at of immersion $(100 \mathrm{X})$ for measurement of the spores. The micrographs were took using Olympus BX-51 microscope with Phase Contrast 100X.

The characteristics used for the description of the new species are according to Lom and Arthur $^{21}$. The spores were treated with Lugol solution to determine the presence of iodinophilous vacuoles in the sporoplasma. For the detailed observation, description and drawing of the species, the spores were stained with Giemsa, according an standard protocol ${ }^{22}$.

The syntypes are deposited at the Coleção Helmintológica do Instituto Oswaldo Cruz (CHIOC), Rio de Janeiro, Brazil.

\section{RESULTS}

\section{Henneguya guanduensis n. sp. (Figures 1} and 2)

Cysts polysporic $0.06-0.30 \times 0.08-0.38 \mathrm{~mm}$ in diameter. Development was synchronous. Cysts in advanced stages contained only mature spores. Mature fresh spores surface smooth,

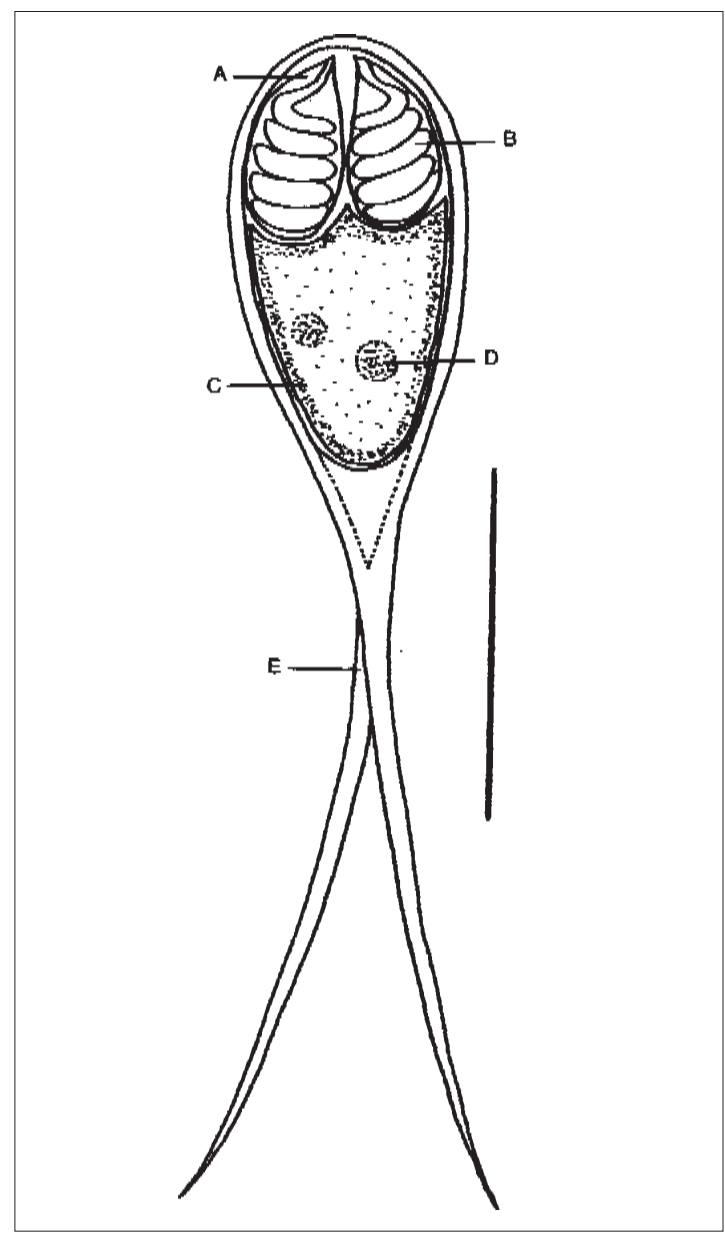

Figure 1. Sche-matic drawing of spore of Henne-guya guanduensis n. sp.; A) polar capsules, B) polar filaments, C) sporo-plasm, D) nucleus and E) tail $(-=10 \mu \mathrm{m})$. 


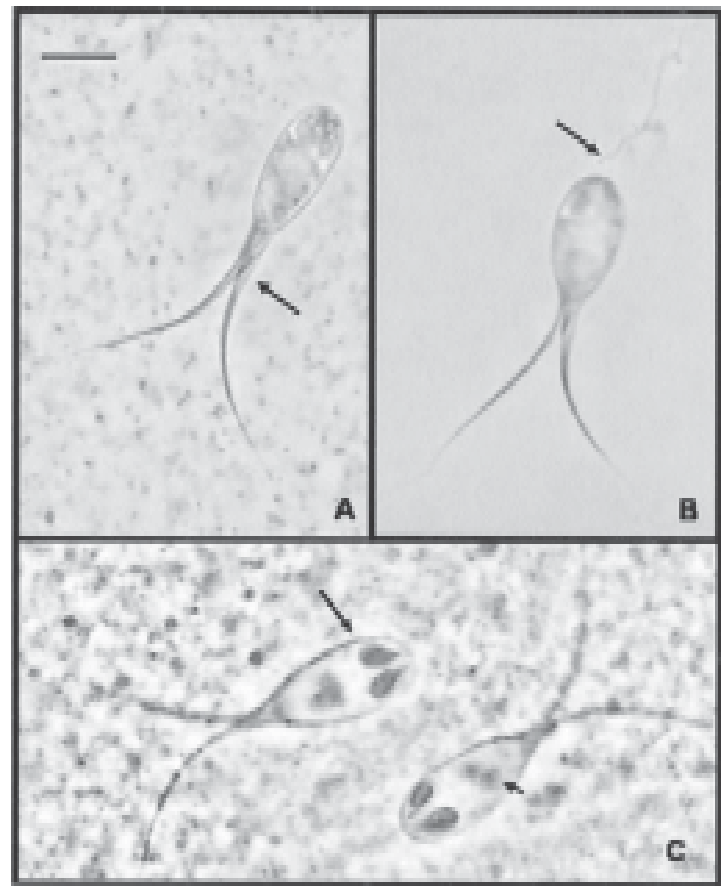

Figure 2. Spore of Henneguya guanduensis n. sp. collected of gills of Hoplosternum littorale from Guandu River, State of Rio de Janeiro, Brazil; A- Tail open $(\rightarrow)$; B- Polar filament extrovert $(\rightarrow)$; C - Polar capsules, unequal in size $(\rightarrow)$ and sporoplasm binucleate $(\rightarrow)(-=$ $10 \mu \mathrm{m})$.

with symmetric valves. Total length $33.6(27.3$ 38.1) $\mu \mathrm{m}$, body length 14.6 (11.4 - 16.7) $\mu \mathrm{m}$, body width $6.5(4.9-7.9) \mu \mathrm{m}$, tail length 19.0 (15.6 - 22.5) $\mu \mathrm{m}$. Distance from anterior extremity to polar capsule $1.5(0.6-2.1) \mu \mathrm{m}$. Two polar capsules in the anterior pole of spore, unequal in size, elongate, more or less cylindrical, anterior extremity tapered. Polar capsules near one of the other, not leaning; Larger 4.4 (3.35.6) $\mu \mathrm{m}$ long, 2.0 (1.6 - 2.3) $\mu \mathrm{m}$ wide; smaller 4.1 (3.3 - 5.3) $\mu \mathrm{m}$ long, $2.2(1.5-2.8) \mu \mathrm{m}$ wide; 3 - 6 coils in the polar filament, obliquely to axis polar capsule. Tail not bifurcated at the end of spore body. Iodinophilous vacuole absent. Sporoplasm binucleate. Mucous envelope present.

- Type host: Hoplosternum littorale, Callichthyidae, "tamboatá".

- Type locality: Guandu River, (2248’32"S, $\left.43^{\circ} 37^{\prime} 35^{\prime \prime} \mathrm{W}\right)$, State of Rio de Janeiro, Brazil.

- Site of infection: Gills.
- Prevalence: 83 in 100 fishes were infected.

- Etymology: the specific name derives from the type locality.

- Syntypes: CHIOC No.

\section{Henneguya cyphocharax n. sp. (Figures 3 and 4)}

Cysts polysporic $0.10-0.32$ x $0.12-0.35 \mu \mathrm{m}$ in diameter. Development was synchronous. Cysts in advanced stages contained only mature spores. Mature fresh spores surface smooth, symmetric valves. Total length 35.1 (29.6 - 44.4) $\mu \mathrm{m}$, body length $11.3(7.7$ - 13.4) $\mu \mathrm{m}$, body width 4.4 (2.9 - 6.3) $\mu \mathrm{m}$, tail length 23.7 (20.8 31.5) $\mu \mathrm{m}$. Distance from anterior extremity to polar capsule $1.2(0.7-1.6) \mu \mathrm{m}$. Two polar

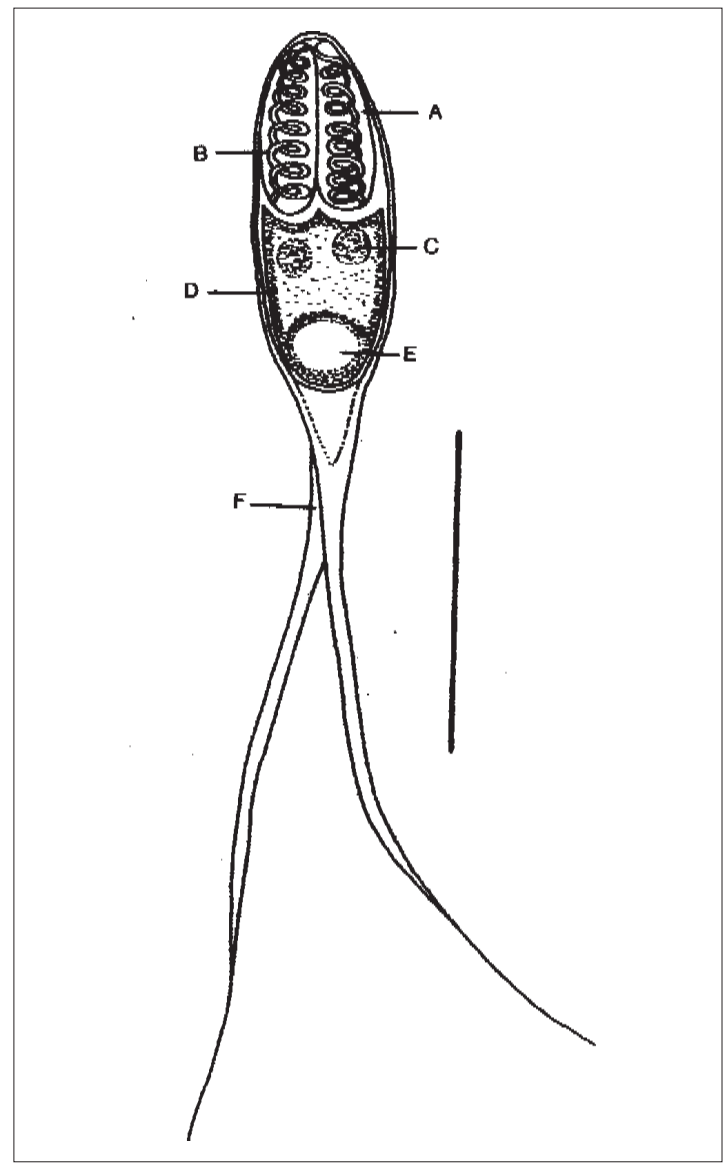

Figure 3. Schematic drawing of spore of Henneguya cyphocharax n. sp.; A) polar capsules, B) polar filaments, C) nucleus, D) sporoplasm, E) vacuole and F) tail (--- = $10 \mu \mathrm{m})$ 


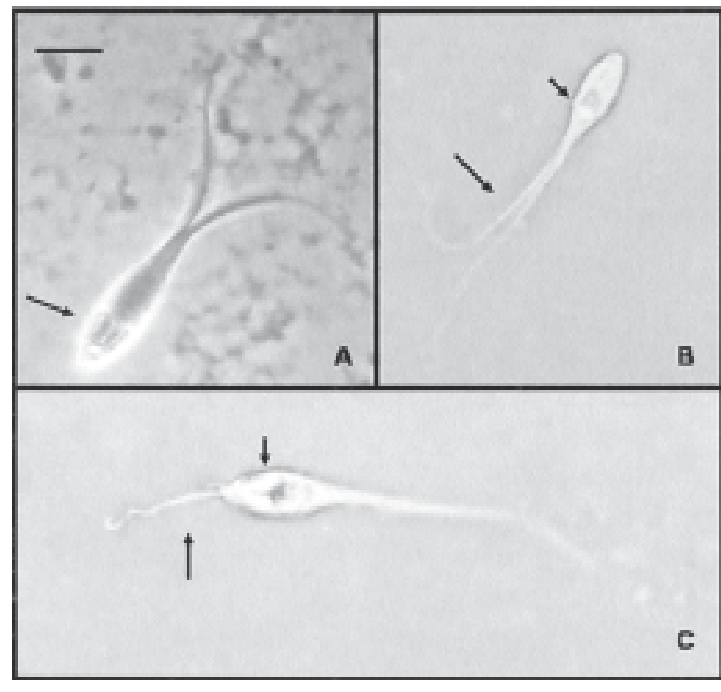

Figure 4. Spore of Henneguya cyphocharax n. sp. Collected of gills of Cyphocharax gilbert from Guandu River, State of Rio de Janeiro, Brazil; A- Polar capsules with polar filaments spiraled appearance $(\rightarrow)$; BSporoplasm with iodinophilous vacuole $(\vec{\rightarrow})$ and tail $(\rightarrow)$; C - Polar capsules, unequal in size $(\rightarrow)$ with filament extrovert $(\rightarrow)(-=10 \mu \mathrm{m})$.

capsules in the anterior pole of spore, well unequal in size, elongate, anterior extremity tapered. Polar capsules near one of the other if leaning; Larger 5.2 (4.2 - 6.3) $\mu \mathrm{m}$ long, 1.9 (1.5 - 2.3) $\mu \mathrm{m}$ wide; smaller 4.5 (3.4 - 5.2) $\mu \mathrm{m}$ long, 1.7 (1.3-2.2) $\mu \mathrm{m}$ wide; 7 - 9 coils in the polar filament, perpendicularly, with spiraled appearance. Tail not bifurcated at the end of spore body. Iodinophilous vacuole present. Sporoplasm binucleate. Mucous envelope absent.

- Type host: Cyphocharax gilbert, Curimatidae, "sairú".

- Type locality: Guandu River, (2248'32"S, $\left.43^{\circ} 37^{\prime} 35^{\prime \prime} \mathrm{W}\right)$, State of Rio de Janeiro, Brazil.

- Site of infection: Gills.

- Prevalence: 51 in 60 fishes were infected.

- Etymology: the specific name derives from the name of the host species.

- Syntypes:CHIOC No.

\section{DISCUSSION}

Henneguya guanduensis n. sp. was first compared with the other Henneguya species described from Brazilian fishes. Only three species showed a general morphology and total length similar to $H$. guanduensis n. sp.: $H$. adherens Azevedo and Matos, 1995; H. curimata Azevedo and Matos, 2002 and H. pellucida Adriano, Arana and Cordeiro, 2005. Henneguya adherens described from Acestrorhynchus falcatus (Bloch, 1794) differ from H. guanduensis n. sp. because it has smaller length and width of polar capsules, smaller number of coils in the polar filament and asymmetry the valves. Henneguya curimata described from Curimata inormata Vari, 1989 is quite different from H. guanduensis n. sp. because it has the larger length and smaller width of polar capsules and higher number of coils in the polar filament. Henneguya pellucida described from Piaractus mesopotamicus differs from $H$. guanduensis $\mathrm{n}$. sp. because it has smaller body length, larger tail and smaller body width (Table 1).

Our species was also compared with spore characteristics of 146 species of Henneguya, including listed by Eiras ${ }^{2}$. Only three species have morphology general and total length similar to $H$. guanduensis n. sp.: $H$. laterocapsulata Landsberg, 1987 in Israel, H. mystusia Sarkar 1985 in India and H. nyongensis Fomena and Bouix, 1996 in Cameroon. Henneguya laterocapsulata described from Clarias lazera Valenciennes, 1840 has smaller body width, larger length of polar capsules and larger size of cysts. Henneguya mystusia described from Mystus sp. differentiates by smaller body length and very much smaller body width, larger length and smaller width of polar capsules. Finally, Henneguya nyongensis described from Marcusenius moorii has smaller body length and smaller body width, larger tail and larger length of polar capsules (Table 1).

Henneguya guanduensis n. sp. was also compared with $H$. amazonica ${ }^{23}$ parasitizing the ovarian follicles from Hoplosternum littorale, but measurements are quite different compared with our species, showed larger tail length (45.4 $\mu \mathrm{m})$, smaller length of polar capsules $(3.3 \mu \mathrm{m})$ and smaller size of cysts $(0.05-0.15)$.

The same comparision was accomplished to Henneguya cyphocharax n. sp. Only two species described from Brazilian fishes showed a general morphology and total length similar to $H$. cyphocharax n. sp.: H. electrica Jakowzka and Nigrelli, 1953 and $H$. friderici Casal, Matos and Azevedo 2003. Henneguya electrica described from Electrophorus electricus (Linnaeus, 1766) 
Two new species of Henneguya parasitic on the gills - V. D. Abdallah et al.

Table 1. Comparison of measurements $(\mu \mathrm{m})$ from Henneguya guanduensis n. sp. with species from Henneguya more near morphologic

\begin{tabular}{lllcccc}
\hline Species & $\begin{array}{l}\text { Total } \\
\text { length }\end{array}$ & $\begin{array}{l}\text { Body } \\
\text { length }\end{array}$ & $\begin{array}{c}\text { Tail } \\
\text { length }\end{array}$ & $\begin{array}{c}\text { Body } \\
\text { width capsule capsulecoils in } \\
\text { length width the polar }\end{array}$ \\
\hline
\end{tabular}

\begin{tabular}{|c|c|c|c|c|c|c|c|c|c|c|}
\hline \multicolumn{11}{|l|}{ H. guanduensis } \\
\hline n. sp. & -38.1 & $11.4-16.7$ & $15.6-22.5$ & $4.9-7.9$ & $3.3-5.6$ & $1.5-2.8$ & $3-6$ & $0.18 \times 0.19$ & gills & This study \\
\hline H. adherens & 32.3 & 12.4 & 20.5 & 5.8 & 3.1 & 1.2 & $3-4$ & $0.2-0.3$ & gills & $\begin{array}{r}\text { Azevedo } \\
\text { and Matos } \\
(1995)^{14}\end{array}$ \\
\hline H. curimata & 35.4 & 16.6 & 19.1 & 6.2 & 6.5 & 1.2 & $10-11$ & $0.05-0.11$ & kidney & $\begin{array}{r}\text { Azevedo } \\
\text { and Matos } \\
(2002)^{16}\end{array}$ \\
\hline H. pellucida & 33.3 & 11.4 & 24.1 & 4.1 & 4.0 & 1.6 & - & $0.5-3.0$ & gills & $\begin{array}{r}\text { Adriano } \\
\text { et al. }(2005)^{9}\end{array}$ \\
\hline H. laterocapsulata & 32.7 & $13.8-16.0$ & $15.2-20.2$ & $3.7-5.3$ & $4.1-5.3$ & $2.2-3.0$ & $5-6$ & $0.5-0.7$ & dermis & $\begin{array}{r}\text { Landsberg } \\
(1987)^{25}\end{array}$ \\
\hline H. mystusia & 32.3 & $12.0-15.0$ & $17.0-25.0$ & $3.0-4.0$ & $5.0-6.0$ & $1.0-1.3$ & - & $0.1-0.2$ & gills & $\begin{array}{r}\text { Sarkar } \\
(1985)^{26}\end{array}$ \\
\hline H. nyogensis & 33.6 & $10.0-14.0$ & $20.0-23.5$ & $4.5-6.5$ & $5.5-7.0$ & $2.0-2.8$ & $4-5$ & $\begin{array}{r}0.04-0.27 x \\
0.03-0.17\end{array}$ & $\begin{array}{r}\text { gills, } \\
\text { muscle }\end{array}$ & $\begin{array}{l}\text { Fomena and } \\
\text { Bouix }(1996)^{27}\end{array}$ \\
\hline
\end{tabular}

Table 2. Comparison of measurements $(\mu \mathrm{m})$ from Henneguya cyphocharax $n$. sp. with species from Henneguya more near morphologic

\begin{tabular}{|c|c|c|c|c|c|c|c|c|c|c|c|}
\hline Species & $\begin{array}{l}\text { Total } \\
\text { length }\end{array}$ & $\begin{array}{c}\text { Body } \\
\text { length }\end{array}$ & $\begin{array}{c}\text { Tail } \\
\text { lengtl }\end{array}$ & $\begin{array}{r}\text { Body } \\
\text { h widt }\end{array}$ & $\begin{array}{l}\text { y Polar } \\
\text { hcapsule } \\
\text { lengt }\end{array}$ & $\begin{array}{c}\text { Polar } \\
\text { capsule } \\
\text { width }\end{array}$ & $\begin{array}{r}\text { Numb } \\
\text { coils } \\
\text { in th } \\
\text { polar } \\
\text { infecti }\end{array}$ & $\begin{array}{l}\text { ser } \\
\text { s } \\
\text { the } \\
\text { ir } \\
\text { ion }\end{array}$ & $\begin{array}{c}\text { Cyst } \\
(\mathbf{m m})\end{array}$ & \multicolumn{2}{|c|}{$\begin{array}{l}\text { Site of References } \\
\text { filament }\end{array}$} \\
\hline \multicolumn{12}{|l|}{ H. cyphocha- } \\
\hline rax. n sp. & $29.6-44.4$ & $7.7-13.420$ & $.8-31.5$ & $2.9-6.3$ & $3.4-6.3$ & $1.3-2.3$ & $\begin{array}{ll}7-9 & 0\end{array}$ & 0.21 & $1 \times 0.23$ & gills & This study \\
\hline H. electrica & $35-39$ & $11-13$ & $24-27$ & $6-8$ & $5-7$ & 2.0 & - & & - & $\begin{array}{l}\text { eletric } \\
\text { organs }\end{array}$ & $\begin{array}{r}\text { Jakowska } \\
\text { and Negrelli } \\
(1953)^{28}\end{array}$ \\
\hline H. friderici & 33.8 & $9.6-11.819$ & $.1-28.7$ & $4.8-6.6$ & $4.25-5.91$. & $.59-2.62$ & $7-8$ & & - & $\begin{array}{r}\text { gills, sev. } \\
\text { organs }\end{array}$ & $\begin{array}{r}\text { Casal et al } \\
(2003)^{3}\end{array}$ \\
\hline H. australis & 33.0 & $11-15$ & 20.0 & $3-5$ & $5-6$ & $1-2$ & - & & - & gills & $\begin{array}{r}\text { Johnston and } \\
\text { Bancroft } \\
(1919)^{29}\end{array}$ \\
\hline H. shaharini & 35.0 & $10.6-12.321$ & $.8-28.0$ & $2.8-3.9$ & $5.6-6.7$ & $1.1-1.7$ & $3-7 \quad 0$ & 0.27 & $7 \times 0.14$ & gills & $\begin{array}{r}\text { Shariff } \\
(1982)^{30}\end{array}$ \\
\hline
\end{tabular}

differs from $H$. cyphocharax n. sp. because it has larger body length, larger body width and smaller tail. $H$. friderici described from $L$. friderici differs from $H$. cyphocharax n. sp. because it has smaller length and larger body width, smaller number of coils of the polar filament and polar capsules in equal size (Table 2).
After the comparison with the spore characteristics of 146 species of Henneguya, listed by Eiras², only two species had a morphology general and total length similar to $H$. cyphocharax n. sp.: H. australis Johnston and Bancroft, 1919 in Austrália and H. shaharini Shariff, 1982 in Malaysia. Henneguya australis described from Plectroplites ambiguus Richar- 
dson, 1845 has smaller tail length, smaller body width, larger body length and smaller length of polar capsules; Henneguya shaharini described from Oxyeleotris marmoratus (Bleeker, 1852) has very much smaller body width, larger length and smaller width of polar capsules and smaller number of coils of the polar filament (Table 2). Additionally $H$. cyphocharax n. sp. was compared with $H$. singhi Lalita-Kumari, $1969^{24}$ described in India from Notopterus osmanii Rahimullah and Das, 1991, due to the similarity of the general morphology and of some measured, in spite of the difference among the total length $(51.3 \mu \mathrm{m})$, tail length $(39.0 \mu \mathrm{m})$ and polar capsule length $(5.7 \mu \mathrm{m})$, that healthy much larger than Henneguya cyphocharax $\mathrm{n}$. sp.

Henneguya cyphocharax n. sp was also compared with $H$. garavelli Martins and Onaka, 2006 found parasitizing the gills from Cyphocharax nagelli, whose measures are quite different compared with our species, showed larger total length $(46.6 \mu \mathrm{m})$, larger body length $(13.6 \mu \mathrm{m})$, larger tail $(33.0 \mu \mathrm{m})$ and larger length of polar capsules $(5.4 \mu \mathrm{m})$.

\section{REFERENCES}

1.- KENT M L, ANDREE K M, BARTHOLOMEW J L, et al. Recent advances in our knowledge of the Myxozoa. J Eukar Microbiol 2001; 48: 395-413.

2.- EIRAS J C. Synopsis of the species of the genus Henneguya Thélohan, 1892 (Myxozoa: Myxosporea: Myxobolidae). Syst Parasitol 2002; 52: 43-54.

3.- CASAL G, MATOS E, AZEVEDO C. Ligth and electron microscopic study of the myxosporean Henneguya friderici $\mathrm{n}$. $\mathrm{sp}$. from the Amazonian teleostean fish, Leporinus friderici. Parasitology 2003; 126: 313-9.

4.- AZEVEDO C, MATOS E. Fine structure of Henneguya pilosa sp. n. (Myxozoa: Myxosporea), parasite of Serrasalmus altuvei (Characidae), in Brazil. Folia Parasitol 2003; 50: 37-42.

5.- BARASSA B, ADRIANO E A, ARANA S, CORDEIRO N S. Henneguya curvata sp. n. (Myxosporea: Myxobolidae) parasitizing the gills of Serrasalmus spilopleura (Characidae: Serrasalmidae), a South American freshwater fish. Folia Parasitol 2003; 50: 151-3.

6.- EIRAS J C, MALTA J C, VARELA A, PAVANELLI G C. Henneguya schizodon n. sp. (Myxozoa, Myxobolidae), a parasite of the amazonian teleost fish Schizodon fasciatus (Characiformes, Anostomidae). Parasite 2004; 11: 169-73.

7.- EIRAS J C, PAVANELLI G C, TAKEMOTO R M. Henneguya paranaensis sp. n. (Myxozoa, Myxobolidae), a parasite of the teleost fish Prochilodus lineatus (Characiformes, Prochilodontidae) from the
Paraná River, Brazil. Bull Eur Ass Fish Pathol 2004; 24: 308-11.

8.- ADRIANO E A, ARANA S, CORDEIRO N S. Histophatology and ultrastructure of Henneguya caudalongula sp. n. infecting Prochilodus lineatus (Pisces: Prochilodontidae) cultivated in the state of São Paulo, Brazil. Mem Inst Oswaldo Cruz 2005; 100: 177-81.

9.- ADRIANO E A, ARANA S, CORDEIRO N S. An ultrastructural and histopathological study of Henneguya pellucida n. sp. (Myxosporea: Myxobolidae) infecting Piaractus mesopotamicus (Characidae) cultivated in Brazil. Parasite 2005; 12: 221-7.

10.- MATOS E, TAJDARI J, AZEVEDO C. Ultrastructural studies of Henneguya rhamdia n. sp. (Myxozoa) a parasite from the Amazon teleost fish, Rhamdia quelen (Pimelodidae). J Eukar Microbiol 2005; 52: 532-7.

11.- MARTINS M L, ONAKA E M. Henneguya garavelli n. sp. and Myxobolus peculiaris n. sp. (Myxozoa: Myxobolidae) in the gills of Cyphocharax nagelli (Osteichthyes: Curimatidae) from Rio do Peixe Reservoir, São José do Rio Pardo, São Paulo, Brazil. Vet Parasitol 2006; 137: 253-61.

12.- GIOIA I, CORDEIRO N S, ARTIGAS P L. Henneguya intracornea n. sp. (Myxozoa: Myxosporea) parasita do olho de lambari, Astyanax scabripinnis (Jenys, 1842) (Osteichthyes, Characidae). Mem Inst Oswaldo Cruz 1986; 81: 401-7.

13.- ROCHA E, MATOS E, AZEVEDO C. Henneguya amazonica n. sp. (Myxozoa, Myxobolidae), parasitizing the gills of Crenicichla lepidota Heckel, 1840 (Teleostei, Cichlidae) from Amazon river. Europ J Protist 1992; 28: 273-8.

14.- AZEVEDO C, MATOS E. Henneguya adherens $\mathrm{n}$. sp. (Myxozoa, Myxosporea), parasite of the Amazon fish, Acestrorhynchus falcatus. J Eukar Microbiol 1995; 42: $515-8$.

15.- AZEVEDO C, MATOS E. Henneguya malabarica sp. nov. (Myxozoa, Myxobolidae) in the Amazonian fish Hoplias malabaricus. Parasitol Res 1996; 82: 222-4.

16.- AZEVEDO C, MATOS E. Fine structure of the Myxosporean, Henneguya curimata n. sp. Parasite of the Amazion fish, Curimata inormata (Teleostei, Curimatidae). J Eukar Microbiol 2002; 49: 197-200.

17.- VITA P, CORRAL L, MATOS E, AZEVEDO C. Ultrastructural aspects of the myxosporean Henneguya astyanax n. sp. (Myxozoa: Myxobolidae), a parasite of the Amazonian teleost Astyanax keithi (Characidae). Dis Aquat Org 2003; 53: 55-60.

18.- BARASSA B, CORDEIRO N S, ARANA S. A new species of Henneguya, a gill parasite of Astyanax altiparanae (Pisces: Characidae) from Brazil, with comments on Histopathology and Seasonality. Mem Inst Oswaldo Cruz 2003; 98: 761-5.

19.- MCCLELLAND R S, MURPHY D M, CONE D K. Report of spores of Henneguya salminicola (Myxozoa) in human stool specimens: possible source of confusion with humana spermatozoa. J Clin Microbiol 1997; 35: 2815-8.

20.- BIZERRIL C R S F, PRIMO P B da S. Peixes de águas Interiores do Estado do Rio de Janeiro. Fundação de Estudos do Mar. 2001, 417pp. 
21.- LOM J, ARTHUR J R. A guideline for the preparation of species description in Myxosporea. J Fish Dis 1989; 12: 151-6.

22.- MEYERS T R, SAWYER T K, MACLEAN S A. Henneguya sp. (Cnidospora: Myxosporea) parasitic in the heart of the bluefish, Pomatomus salatrix. J Parasitol 1977; 63: 890-6.

23.- TORRES A, MATOS E, AZEVEDO C. Fine structure of Henneguya amazonica (Myxozoa) in ovarian follicles of Hoplosternum littorale (Teleostei) from the Amazon River. Dis Aquat Org 1994; 19: 169-72.

24.- LALITHA-KUMARI P S. Studies on parasitic protozoa (Myxosporidia) of freshwater fishes of Andhra Pradesh, India. Riv Parassitol 1969; 30: 154-225.

25.- LANSBERG J H. Myxosporean parasites of the catfish, Clarias lazera (Valenciennes). Syst Parasitol 1987; 9: 73-81.

26.- SARKAR N K. Myxosporidian Henneguya mystusia sp. n. (Myxozoa: Myxosporea) from the gills of a fresh water teleost fish Mustus sp. Acta Protozool 1985; 24: 55-8.

27.- FOMENA A, BOUIX G. New species of Henneguya
Thélohan, 1892 (Myxozoa: Myxosporea) parasites of freshwater fishes in Cameroon. J Afric Zool 1996; 110: 413-23.

28.- JAKOVSKA S, NIGRELLI R F. The pathology of myxosporidiosis in the electric eel, Electrophorus electricus (Linnaeus), caused by Henneguya visceralis and Henneguya electrica spp. nov. Zoologica 1953; 38: $183-91$

29.- JOHNSTON T H, BANCROFT M J. Some new sporozoan parasites of Queesland freshwater fish. J Proc R Soc NSW 1919; 52: 520-8.

30.- SHARIFF M. Henneguya shaharini sp. nov. (Protozoa: Myxozoa), a parasite of marble gogy, Oxyeleotris marmoratus (Bleeker). J Fish Dis 1982; 5: 37-45.

Acknowledgements: Jose L. Luque was supported by a Research fellowship from CNPq (Conselho Nacional de Pesquisa e Desenvolvimento Tecnológico). Vanessa D. Abdallah and Rodney K. Azevedo were supported by student fellowships from CAPES (Coordenação de Aperfeiçoamento de Pessoal de Nível Superior) and CNPq, respectively.

\section{Correspondencia a:}

e-mail: 1tcbb@ufrrj.br

jlluque@ufrrj.br abdallahvd@ufrrj.br azevedork@ufrrj.br

\section{ANUNCIO}

\section{PARASITOLOGIA LATINOAMERICANA EN INTERNET}

Información sobre Parasitología Latinoamericana y su versión electrónica se puede ahora encontrar en Internet. Dirección: www.scielo.cl 